\title{
Defining Rights from the Roots: Insights from Council Tenants' Struggles in Mombasa, Kenya
}

\section{Samuel Musyoki and Celestine Nyamu-Musembi*}

\section{Introduction}

As the language of rights and rights-based approaches begins to become commonplace in development at the rhetorical level, it becomes necessary to move the discussion beyond conceptual debates to actual practice. So far, most writings that have tried to do this have focused on practice at the level of multilateral and bilateral agencies and prominent international non-governmental organisations (NGOs), with only cursory glimpses at the practices of grassroots-based movements (Nyamu-Musembi and Cornwall 2004; NyamuMusembi and Musyoki 2004; Harris-Curtis 2003; Offenheiser and Holcombe 2001; Molyneux and Lazar 2003).

This article documents and discusses the experiences of a movement of low-income council tenants in three housing estates in Mombasa, Kenya's largest coastal city. The focus of the struggle has been on attaining secure and dignified living conditions. The tenants' struggle illustrates that there is not only clear articulation of rights at the grassroots level, but also the seeds for an expansion of the arena of legally recognised rights as well as an innovative combination of strategies for realising rights and forcing institutions to be accountable and responsive. This points to the potential of grassroots movements to be the driving force for a more sustainable practice of rights and rights-based development, a point that cannot be overstated in the context of Kenya where professional rights advocacy groups are only beginning to support and take account of the contribution that grassroots movements make to the practice of human rights (Nyamu-Musembi and Musyoki 2004).

This article is organised into six sections.
Following the Introduction, the second section provides the background and context of the tenants' struggle, highlighting the problems in response to which the tenants decided to organise and the rights they believe they hold as tenants of the council. The third section discusses the identity of the groups from their own perspective and in relation to their struggle. The fourth section elaborates on the different strategies the tenants employ in pursuing their rights, evaluating their strengths and weaknesses. The fifth section concludes by drawing key insights emerging and comments on how these insights could inform thinking on rights and rightsbased approaches beyond this specific struggle.

\section{Background and context}

Mombasa is the second largest city in Kenya. The city has a population of about half a million inhabitants. The coastal town, located in the South Eastern part of Kenya along the Indian Ocean, plays an important role in the country's economy, not only for its imports and exports through its port, the largest in East Africa, but also as a destination for tourists visiting Kenya. In spite of its strategic economic importance however, it is estimated that about 44 per cent of the population in Mombasa live below the poverty line (Kenya Central Bureau of Statistics 2003).

Good quality housing for low- and middleincome inhabitants of the city is in short supply. Most people in this income group have only two options to choose from: either the Swahili type houses (built out of mud and mangrove poles), occupied by several families with no sanitation services as they are located in unplanned semipermanent settlements; or council-owned estates 
constructed in the colonial era, which have not seen much maintenance since the mid-1980s. Among these estates are Tudor, Changamwe and Mzizima, which are the focus of this article. ${ }^{1}$

The Tudor estate occupies an area of roughly 40 acres, with a population of 15,000 to 20,000 living in 930 housing units. The population estimate includes the slum settlements that have mushroomed on the fringe of the estate since the late 1980s. Tudor started off as a tented camp in 1948 for African soldiers returning from Burma. Construction of the housing estate began in 1952-3 and the houses were intended for government workers. Changamwe occupies an area of 28 acres, with 1102 housing units occupied by approximately 43,000 residents. Construction of the section referred to as the "old estate" was completed in 1956 , and it was occupied by workers employed by, e.g. the council; Cargo Handling Ltd. and other companies. Construction of the "new flats" started in 1969 and was completed in 1971. Mzizima is a 7 -acre plot of prime beach-front land housing around 2000 people in 114 units. Mzizima started off as an army base during World War II, for the Kenya African Rifles (KAR). Some of the housing units were actually the stables for the horses. The base was subsequently made into a residence for people suffering from leprosy and then a quarantine area for people suffering from communicable diseases. The estate now houses low-cadre employees of the council.

Residents from the three estates recall that through the immediate post-independence period and into the early 1980s, the council used to carry out regular maintenance. Sometime in the mid1980s, they remember receiving letters stating that they would henceforth be required to share the cost of maintenance. ${ }^{2}$ Since then, the council has done nothing by way of routine maintenance. An elderly resident of Mzizima remembers that the last time the houses got a new coat of paint was 1983. The houses are dilapidated. Some have already been condemned as unfit for human habitation, but still continue to be occupied. The council's mantra is that it has no money, that the rent collected from the estates is not enough to pay for basic services, let alone finance major repairs.

The tenancy agreements require tenants to seek permission from the council before they undertake any repairs. The council always denies permission, putting the tenants in a no-win situation: tenants have no choice but to undertake the repairs anyway in order to make the houses habitable. Then the council is under no obligation to reimburse the tenants for the cost of the repairs, since it did not authorise the repairs. When a tenant leaves they are not allowed to remove any fittings they may have added or replaced in the house, such as new windows, doors, toilet seats or sinks.

There has been total breakdown of water and sewerage services. The established practice is that the tenants pay for water and sewerage services as part of their rent, so that the council can remit the water charge to the Ministry of Water who supply the service. However, the council has consistently failed to remit the water charge and therefore the Ministry of Water undertook a massive disconnection campaign, leaving the estates with no running water, even though the tenants continue to pay water levy as part of their rent. In Tudor, residents have resorted to boreholes sunk by women's self-help groups and the purchase of water from mobile water vendors.

Piles of uncollected rubbish have become part of the landscape and there has been a physical collapse of facilities such as public toilets and markets. As in other urban centres in Kenya, the 1990s were marked by corrupt "grabbing" of every bit of open space and community amenities, such as social halls and playgrounds. These have been converted into shops and other businesses by people with connections in the council, leaving residents with no amenities.

In the mid-1990s a new threat emerged. Without consulting or even informing the tenants, the council entered into various deals to sell off the Tudor and Mzizima housing estates to private developers, with massive evictions planned. This, along with the grabbing of public utilities and open spaces, was the issue that triggered the formation of Tenants' Associations in each of the estates. Initially the agenda was a reactive one: to resist eviction and undertake direct action to demolish walls constructed by private developers to fence off illegally acquired plots. Now the goals have become proactive: in the short term, to get the council to carry out urgent repairs such as roofing and in the long term, to secure the right to purchase the houses. The Tenants' Associations in the three estates would like council tenants to have the right to purchase the houses and maintain them at their own expense. All housing developments initiated 
by the council in the 1950s were initially intended as Tenant Purchase Schemes, where the tenants would acquire ownership of the houses after 25 years. The tenants claim that this plan was contained in the minutes of the Municipal Board of Mombasa, the unelected body that managed the town prior to independence in 1963. That resolution was apparently reversed when the postindependence council took over. It was decided that the council would own the houses and manage them as rental units in order to generate revenue for the council.

\section{Identity of the group}

The Tenants' Associations see their collective identity as Wakereketwa. They defined this term as follows: many people may be affected by an issue, but not all of them will speak out. There are those people who love haki (justice) and will speak out and take action to redress injustice, whether that injustice is directed at them or at someone else. They define themselves in opposition to Wafurukutwa: people who are unlikely to get involved in a struggle and if they do get involved, it is for their own personal and immediate gain and therefore they are easily bought off.

The Tenants' Associations in the respective council estates began in the mid-1990s. They began to work together in November 2002 and set up a joint leadership in the form of a joint committee to advocate on the poor condition of the estates. The joint committee had a membership of 30 , ten from each estate. They then became members of ILISHE (a Kiswahili acronym for 'rights awareness'), an umbrella advocacy network of community-based groups working on diverse rights issues in the coastal region. Initially the Tenants' Associations formed part of the Land and Shelter Committee within ILISHE, which also incorporated groups engaged in struggles to secure title to rural land. Since June 2004 however, the tenants have succeeded in establishing a Shelter and Housing Committee. For two years they had argued persistently that as much as they valued solidarity, the specific issues confronting urban tenants of the council are quite distinct from those facing farmers' cooperatives and other rural community groups and it did not make sense to lump the issues together.

The Tenants' Associations intend to reach out beyond the three estates and mobilise tenants in all the council estates in Mombasa (18 in total), so as to build a mass movement and a stronger voice to exert more pressure on the council and to demonstrate that the issue profile has the broader problem of council management of housing, as opposed to grievances peculiar to these three estates. As of July 2004, they had managed to recruit eight other estates, raising the number of estates represented on ILISHE's Shelter and Housing Committee to 11.

The Tudor and Mzizima committees are largely constituted by women and male youths who are also active in various self-help groups. The Tudor committee in particular acknowledges having had difficulty in mobilising older men to take an active role in the association. The women attribute this partly to the fact that some of the prominent men in the estate are implicated in the irregular sale of open spaces and they are also landlords in the slum settlements that have mushroomed around the estate and which have contributed to the sanitation problem. They therefore do not want the Associations to succeed.

Although the Tenants' Associations are focused on their specific struggle for housing, they do not see themselves only as people lacking adequate housing. Housing issues have brought them together to form the associations, but their organising efforts have made visible the unresponsiveness of institutions that should be serving them. Joining together has made them realise that when they act together they can be a powerful voice to question those institutions. And so they speak in terms of seeking change, not just in their housing conditions, but also in the way the council conducts its business, and in the way their elected representatives (councillors and MPs) behave. This is reflected in their taking on broader concerns about corruption in city government as reflected in land grabbing and irregular privatisation and "personalisation" of council housing and their demands that tendering processes be open to public observation by residents.

\section{Strategies employed in the struggles}

The strategies employed by the tenants range from reactive strategies, such as protest and patronage, to proactive and assertive pursuit of their rights as tenants and collective and sustained demand for accountability from local government. The tenants have used these strategies in varying combinations 
depending on the prevailing political environment. The strategies can be classified into seven categories: (1) Community organising, (2) Court action/ litigation, (3) Direct mass action, (4) Naming and shaming, (5) Political patronage, (6) Lobbying the council and (7) Networking and alliance building.

\subsection{Community organising}

As the tenants made clear in defining their identity, not everyone has been involved in taking action to address the problems facing the estates. It is quite understandable why some tenants may not wish to be involved. Despite its poor quality, council housing offers affordable accommodation and is always in demand. Some fear that speaking out will invite trouble with the council and possible eviction, which would result in living in the informal settlement areas of the city.

The risk of reprisals is particularly pronounced for tenants of the Mzizima estate. This is because they are both council tenants and low-cadre council employees. Their rent payments are deducted directly from their salaries. In theory, they can choose whether or not to take up housing in Mzizima, but in practical terms they are "captive tenants". They do not have the choice of living elsewhere. When an employee applies to live away from the council estate, the adjustment to the payroll takes several months and in the meantime, the automatic rent deductions continue to be made and getting the payments refunded is a protracted procedure that could take yet more months. For these reasons, many reluctantly remain. Their wish is that the estate be treated like any other councilowned estate, not as a housing scheme for employees, which means that there would be no automatic deductions from their salaries and they would be free to decide whether to continue living in Mzizima.

For the Tenants' Associations therefore, the work of organising to recruit more residents within the three estates into the struggle, as well as residents of other council-owned estates in Mombasa is a constant activity. They have made extensive use of public forums and awareness-raising campaigns to educate fellow council tenants on their rights as well as develop collective action plans to address the problems facing them. It is no wonder that they speak of these awareness-raising and recruitment activities as kuondoa uoga (removing fear), which is the first step.
The Tenants' Associations have also tried to mobilise estate residents to raise funds, both for the short-term sporadic needs that arise in the course of the struggle, such as payment of fees for a court injunction and the long-term savings schemes that would eventually enable them to purchase the houses from the council. The latter idea came after an exchange visit with the South African Homeless Peoples' Federation. However, mobilisation for long-term fund-raising has not worked well and the Tenants' Associations realise that a lot more on-going work needs to be done to build trust, as the movement expands.

Another weakness that has been noted with respect to their mobilisation strategy, is the underrepresentation of youth. This is a shared problem in the three estates. As one Tudor resident put it, "When we call a meeting and we see that the male elders (wazee) are present, we say 'the residents are here; we can proceed'. A woman from Changamwe rebuked cultural attitudes that do not value the opinions of young people: "We only call on the young people when we want a wall demolished; we do not ask for their views when we are taking the decision'. A young man from Tudor who has been very active in the Tenants' Association explained that there is high unemployment and young people are busy trying to earn their livelihoods. They would need to be persuaded that it is worthwhile to spend their time on the activities of the Tenants' Associations. A Tudor resident urged the associations to make special efforts to meet the youth in the places where the youth normally gather, for instance, their recreation clubs. The youth must feel that their issues - for instance, the need for sporting facilities in the estates - are also a priority for the associations.

Also the associations see a need to intensify outreach activities in the communities and showing of videotapes on the issues affecting the estates has already proved to be a useful outreach tool. They also conduct informal door-to-door visits on an ongoing basis.

\subsection{Court action/litigation}

There is general scepticism about the utility of litigation as a strategy. Their perceived view of legal strategies is that they are too expensive, the courts are corrupt and lawyers are untrustworthy. This view is formed by negative experiences in the past. Tudor tenants have sued the council on two occasions in the past: 
1. In 1994, over water meters: The council had collected contributions from the tenants intended to cover the cost of installing individual water meters for each housing unit instead of having one water meter per block. The meters have never been installed and the money that the council collected was never refunded. The tenants put some money together and engaged a lawyer to take up the claim against the council. The lawyer initiated negotiations for an out-ofcourt settlement, but little is known as to what became of this, as the lawyer has since died. The tenants perceive the whole episode as a double loss, losing money to the council for the elusive water meters and losing money to the lawyer for the lawsuit that never was.

2. In 1995, to challenge the council's decision to increase rent charges: The Tudor Tenants' Association filed and won an application for a temporary injunction to stop the council from increasing the rent. The case did not proceed to a full hearing. It appears that the association did not see any need for this since, as a result of a concerted media campaign, the council dropped the planned increment (East African Standard 1995).

At a workshop in April 2003, many expressed the view that perhaps in the new political climate (following the December 2002 elections that brought a new government to power with the promise of a clean-up of corrupt institutions such as the judiciary), it was worthwhile reconsidering greater use of legal/litigation strategies. They recognised, however, that convincing residents that this is worthwhile will be difficult, given the mistrust generated by past negative experiences. It was decided that the tenants need to understand the laws and policies affecting housing so as to be able to pursue their rights as tenants in an informed manner. Specifically, they feel that they need to understand the relevant by-laws of the city of Mombasa, as this will enable them to engage with the council more effectively. They need this understanding in order to be clear about the exact nature of the obstacles facing them and therefore what strategies to employ in overcoming them, for instance:

- An absence of laws or regulations on a particular issue. If this is the case, then their demand will be that such a law should be put in place. For instance, if the council has not made any specific by-laws to govern its management of estates, providing specific guidelines on how regularly it should carry out maintenance, then the tenants' approach will be to demand that the council be required to do so.

- A law exists but it is not being applied. In this case, their demand will be for implementation. For instance, the legal requirement that notice be given before an eviction, which the council often fails to do.

- A law exists, is being applied, but is unjust in its outcome. In this case, their demand will be that the law be changed and their efforts will be addressed to the council (in the case of a by-law) or to Parliament (in the case of an Act of Parliament). One example is the exemption of government institutions (such as local government councils) from the jurisdiction of the Rent Restrictions Tribunal, an affordable forum for resolving landlord-tenant disputes. This leaves council tenants with the expensive option of pursuing court action whenever they have grievances against their landlord.

Joining ILISHE's shelter and housing committee is seen as strategic and important for the purpose of identifying people and institutions that can provide training on these issues.

\subsection{Direct mass action}

We use this term to refer to instances when the tenants have mobilised and taken defiant action. Instances of this are as follows.

In Changamwe, residents undertook searches at the land registry and investigation through contacts at the council to establish the identity of "grabbers": people who had illegally been allocated title to open spaces such as playgrounds and road reserves in the estate. They then wrote letters to them asking them to abandon their illegal claims and made those letters public. They also had audience with the council several times to complain about the "grabbing" of public spaces.

They have mobilised to demolish structures constructed on illegally acquired land when they were of the view that the authorities failed to act. In one case in April 2002, a wall was illegally constructed around a plot that had been illegally allocated in the Changamwe estate. Following the tenants' campaign, a task force headed by the Provincial Commissioner had recommended that building permission for the plot to be withheld. 
The tenants wrote to the Physical Planning Liaison Committee requesting permission to demolish the wall. When there was no response forthcoming from the committee, the tenants mobilised and tore down the wall. The wall was rebuilt and once again they tore it down resulting in a physical confrontation with the site workers. The private developer then put up a firm stone wall overnight, which still stands to date. The tenants have decided to spare their energy this time around, secure in the knowledge that the new government has revoked those allocations and so the private developer no longer has title to the "grabbed" land and stands to lose the plot anyway.

In Tudor and Changamwe, residents realised that there were corrupt practices being carried out by some councillors and council employees who were turning the council housing into their own private cash cows. Tenants who defaulted on rent or delayed their payments would be evicted without the required notice and hastily replaced with "private tenants". In some cases, the new "tenant" would be asked to make a one-off payment for the house (the councillors were no doubt aware of the finiteness of political office and did not want to risk collecting the "rents" over a long period). It appeared to be common knowledge to the Tenants' Associations that the going price for council houses on the councillors' irregular market was Kshs.70,000 ( £650). In one illustration given by a Tudor resident, a legal tenant who was two months late in paying rent was only served with the notice on the day of the notice's expiration, even though the records show that she was given the required 21-days notice. That same day, her belongings were quickly packed into the municipal council's lorry for which she was required to pay Kshs. 3000 $(\sim £ 25)$. As she was being evicted, the replacement "private tenant" was waiting at the door.

On becoming aware of these irregularities, the tenants have made it regular practice to publicise any imminent eviction, wait for the new "tenant" to move in and then strike at night to evict him/her and reinstate the old tenant. They feel they have a moral justification in doing this because they are challenging the corrupt practices of the council.

\subsection{Naming and shaming: use of media}

Effective use of the media to publicise the struggles is seen as a strategy that has worked well in the past and one that still remains crucial for the tenants' struggles. Having conducted their investigations to establish who the "grabbers" and private developers were, the tenants employed a variety of methods to bring the issues to the attention of the media, the council, and concerned government offices at the national level, such as the Commissioner of Lands, a commission of inquiry that was set up in 2002 (the Njonjo Commission) to look into land matters and recommend ways of combating corruption in the land sector. In Mzizima, when the residents discovered in 1995-6 that their estate had been sold, they investigated and found out who the private developer was and went to the media with this information. They also wrote letters to him, telling him that he ought to consider their welfare, asking whether he thought that as poor people (mostly women) they had no right to live on a beach-front plot. The businessman in question never confirmed or denied that the plot had been allocated to him, even though it was common knowledge that houses that were being constructed on an alternative site (where the Mzizima tenants would have been resettled, since they are council employees) were being built by his company.

In all three estates, the Tenants' Associations have made use of print and electronic media both to publicise their plight to the general public and to address the specific institutions and individuals responsible for it. In April 2003, Tudor residents invited a team from the Kenya Television Network (KTN) to cover a story about a blocked sewer that had overflowed into the estate unattended for months despite complaints from the tenants. In March 2004, KTN also aired a programme in which one representative from the Tenants' Association and representatives from ILISHE and Intermediate Technology Development Group (ITDG, which has been involved in a number of housing projects) took part in a discussion on the crisis in council housing. ${ }^{3}$

One major challenge with this strategy is that the mainstream media has very little commitment to public interest issues. The tenants have not been able to get as much coverage as they would like. The KTN programme in March 2004 for instance, was aired on a Sunday morning, when many church-going Kenyans were unlikely to be tuning in. With the support of ILISHE, the tenants plan to continue cultivating good contacts in mainstream media, but they also see the need to improve the use of alternative media such as theatre, oral testimonies, participatory video, art, music, poetry 
and community radio. They are working towards developing specific strategies for effective use of electronic and print media: systematically identifying key audiences, developing messages and selecting the most appropriate channels of communication.

\subsection{Political patronage}

Stories of visits to political figures seen as powerful and able to intervene on behalf of the tenants are common among the tenants, as are narratives about dashed hopes and betrayals by these same political figures. This practice is not unique to the estates or indeed to coast province. Patronage had become the established practice during the KANU era, normalised through high-profile media coverage of delegations paying visits to State House. In the post-December 2002 political climate, the media coverage of State House visits is gone, but the culture of patronage remains. The Mombasa council tenants have lobbied key coast politicians, yet these same politicians have been implicated in land-grabbing and protecting councillors and council employees responsible for the mismanagement of council estates in Mombasa.

At a workshop in April 2003, the tenants were emphatic about the need to move beyond political patronage and start demanding accountability from the political leaders on the basis that they have election promises to keep, not on the basis of their supposed magnanimity. They suggested mechanisms for engaging with the local councillor and Member of Parliament more effectively on tenancy issues. Among the mechanisms suggested was the formation of a Citizens' Committee (kamati ya wananchi) in each estate to advise the councillor and MP so that they are more informed when they participate in council and parliament decisionmaking processes. The Citizens' Committees would be responsible for organising forums at which tenants could hold discussions with their elected leaders. The committees would also be required to monitor the performance of councillors and MPs on tenancy issues and report back to the tenants.

\subsection{Lobbying the council}

Writing memoranda and sending delegations has been a common strategy used by the tenants associations in the three estates. In the previous KANU-dominated council, engagement with the council was largely confrontational. Lobbying was limited to identifying key officials or councillors whom they viewed as sympathetic to the tenants' plight. Lobbying sometimes entailed approaching councillors and council officials, not necessarily because they were supportive of the struggle, but as a tactful way of cashing in on political differences among the councillors.

The tenants however, express a level of frustration with the huge amount of effort and time that goes into this type of engagement and yet the gains so far have amounted to no more than staving off the worst harms (e.g. keeping grabbers at bay). Not much progress is made proactively and there are not many long-term gains. One woman who has been active in the Tudor Tenants Association analogised their situation to that of a non-poisonous snake: administering vicious bites, but not consuming or finishing off the enemy ("Nilikuwa kama nyoka; nauma mtu na simli!').

In the current political regime, however, the mayor himself and key officials such as the Town Clerk have shown a willingness to listen, and so lobbying has focused centrally on the council as an institution, and taken on a deliberative tone. This comes with its own dangers. First, casting the tenants as supplicants and the mayor as benevolent. The tone of the memoranda and petitions is one of detailing the suffering of the tenants and pleading for the mayor's intervention. The language does not assert that the tenants have rights, least of all that someone or some institution is culpable for neglecting those rights. When we raised this question to a delegation that paid a visit to the mayor in April 2003 their response was that since that mayor had only been in office for four months and this was their first audience with him they would simply present their problems and watch and see whether and how he would act, before deciding what attitude to adopt toward him.

Second, the tenants could be pacified with wellmeaning promises without any firm commitment. But the Tenants' Associations are well aware of this danger. As some put it,

in the previous council the mayor would not listen to us. Now the mayor will talk with us alright; he will even order the town engineer on the spot to take action, but nothing gets done.

Since the new government came to power its most commonly heard complaint is that the coffers 
were looted by the previous regime and therefore there are no resources available. This was the response given to a Tenants' Association's delegation to the mayor's office in April 2003. As the rains had just begun they raised the urgent issue of leaking roofs and requested that the council allocate funds for emergency repairs. The mayor skirted around the specific issue of roofing. Instead he dwelt on what a big problem the condition of the estates was, and how the council was committed to doing all in its power to look for the resources to fix it. He never gave a timeframe. The Changamwe councillor (whom the tenants see as an ally) likened the mayor's response to a critically ill patient who is told to wait for a drug that is yet to be researched in a laboratory abroad, without being offered at least a painkiller in the meantime.

After the visit, the councillor challenged the Tenants' Association members to pin the mayor down by presenting concrete proposals outlining what needs to be done and how, otherwise the lobbying sessions would be turned into a public relations exercise for the mayor. For instance, they could propose that the LATF (Local Authority Transfer Fund, an allocation from central government currently supported by the United Nations Development Programme - UNDP) funds be used for emergency re-roofing, since residents are supposed to have a say in how the funds are used. ${ }^{4}$ They could also propose that the rent collected for a specific period of time be earmarked for the roofing. They could get quotations from various contractors and then challenge the council to show why the rent revenues cannot meet the modest cost.

\subsection{Networking and alliance building}

The Tenants' Associations have built alliances by forming the joint committee and by reaching out to other estates that are faced with similar problems. They have also become members of the ILISHE Trust, which has brought them into contact with other groups advocating on a wide range of issues. Through ILISHE, they have created links with support organisations such as the Legal Advice Centre (Kituo cha Sheria), the Law Society of Kenya, The Coast Rights Forum, Kenya Human Rights Commission and media houses. At the international level, the struggle has attracted an array of allies, including the Swedish NGO for Human Rights, the South African Federation of Homeless People and a similar network in Zimbabwe. On account of the Tenants' Associations' struggles, ILISHE was one of the winners of The Body Shop Human Rights Award for 2002 whose focus was on housing rights. The award ceremony in London gave further visibility and international profile to the struggle.

\section{Key lessons and insights}

The Kenya constitution does not recognise a right to adequate housing (nor does it recognise other economic and social rights such as education and health). However, Kenya has ratified the International Covenant on Economic, Social and Cultural Rights, thereby taking on an obligation to work towards the progressive realisation of this right, to the maximum of the country's available resources. ${ }^{5}$ The tenants' struggle however, does not make explicit reference to this, nor is it the organising framework for the struggle. Referring to the current living conditions in the council houses the tenants simply state that this is no way for a human being to live (hii si hali ya mtu kuishi), thus underlining that a basic sense of utu (personhood; dignity) requires that everyone have a right to live in decent housing. This resonates with the concept of human rights, which is based on the idea that all human beings are equal in dignity, ${ }^{6}$ and therefore human rights principles are about establishing the minimum conditions that make it possible for people to live in dignity. The tenants use the Kiswahili word haki which connotes a sense of entitlement, right, and justice. The tenants' struggle is therefore a struggle for human rights, even in the absence of a reference to the framework that sets out the relevant human rights principles, in this case the International Covenant on Economic, Social and Cultural Rights. This seems like an obvious point to make, but it needs to be stated so as to properly establish grassroots struggles as human rights struggles and counter any assumption that only the specialised practices of professional NGOs count as human rights practice.

Characterising the tenants' struggle as a human rights struggle also signals that it is broader than a struggle for legal rights, in two senses. First, in the nature of the claim they are making. While some of the tenants' claims are about demanding that their existing rights as tenants be respected (e.g. the right to adequate notice before eviction), their ultimate demand, namely the right to buy their own homes, which would give them a priority claim 
should the council decide to sell, is not accorded to them under Kenyan law. They are therefore seeking recognition of an entitlement that is currently outside of the law, thereby seeking to expand the arena of legally recognised rights. Second, in the strategies that they are prepared to use to achieve their goal: they have an ambivalent attitude toward legal strategies. They recognise that even if they do use legal strategies they cannot overstate the importance of strategies aimed at influencing the broader political environment through a redesign of representational structures and active mobilisation at the grassroots.

The tenants' approach to their struggle also suggests that for them, rights are not simply about tangible desired outcomes (such as piped water and a rubbish collection system), but also about taking part in the processes that shape and achieve those desired outcomes: a right to active and meaningful participation in the process of shaping the realisation of rights, so to speak. Thus the tenants simultaneously list among their most important rights as tenants the right to speak freely and to meet freely to discuss issues concerning the estates, the right to articulate their priorities before the council and other institutions that govern them, as represented in the proposal to set up citizen committees, the demand to be present and observe the tendering process at the council and the demand

\section{Notes}

* This article is from a global research initiative called 'Linking Rights and Participation', coordinated by the Participation Group at the Institute of Development Studies (IDS) and Just Associates (JASS), USA, in collaboration with country teams from Brazil, Mexico, Nigeria, Kenya, Zimbabwe, India and Indonesia. For more information see www.ids.ac.uk/ids/particip/research/ rights

1. Unless otherwise stated, the information presented here about the estates was generated by the Tenants' Associations, from historical profiles, collective mapping exercises and interviews with key informants such as elderly residents and one active member of Changamwe Village Development Association, who is a retired councillor and therefore had access to the council's archives. Their findings were then presented and discussed at a workshop in April 2003, which the authors helped to facilitate. See 'Sharing experiences and mapping out strategies for advancing the struggle for shelter rights' (Joint workshop for Tudor, Mzizima and Changamwe Tenants' Associations Mombasa, Kenya, 15 and 24 April 2003). for effective participation in deciding how the LATF funds will be used.

The tenants' usage of haki goes hand in hand with phrases about speaking out, claiming, defending or struggling: kutetea haki (defending rights/justice); kudai haki (demanding rights/justice); kupigania haki (fighting for rights/justice). Their type of rights practice is therefore one of active expression of agency. It is also one that suggests a need to maintain a vigilant attitude in relation to the relevant institutions, rather than expect that those institutions will function in their favour. There is therefore a discernible narrative about amplification of voice in the way the struggle has evolved: from sporadic protest at the margins, to broad-based mobilisation so as to transform structures of power and make them responsive to their needs.

The story of the tenants' struggle is still unfolding, but they have made substantial gains. Fending off well-connected land grabbers during the KANU days is no small feat. Now there is even talk of a national policy on housing, thanks to efforts of groups such as the Tenants' Associations. ${ }^{7}$ Therefore the prospects for progressive realisation of the right to housing, indeed of all rights, lie in concrete struggles of movements at the grassroots level which go beyond simply claiming benefits to a reshaping of institutions through employing a variety of innovative strategies to make the institutions listen and act.

2. This coincides with the introduction of "cost-sharing" in other public services such as health and primary education, which were introduced in the country as a whole as part of the Structural Adjustment Policies required by the World Bank and International Monetary Fund (IMF).

3. Kenya Television Network (KTN) 'Mandhari ya Wiki', 21 March 2004.

4. New guidelines require that for funds to be disbursed under the Local Authority Transfer Fund (LATF), which is co-funded by the United Nations Development Programme (UNDP), every local government must prepare a Local Authority Service Delivery Action Plan (LASDAP), which should be prepared with the full and active participation of local residents and reflect their priorities. Many people do not know this and the council has not taken any trouble to inform residents about it, let alone convene participatory forums to find out what the priorities of each locality are. Instead, a team of technocrats in a specially created unit in the council has been preparing all the proposals. The Changamwe Tenants' Association, in collaboration with their councillor, discovered that the technocrats had decided that 
Changamwe's LATF funds would be used to build a nursery school, but they are challenging that and insisting that the funds be deployed toward emergency roofing. Interview with Changamwe councillor, Celvin Wasonga, 26 April 2003. Changamwe Village Development Committee input to tenants' workshop 'Sharing experiences and mapping out strategies for advancing the struggle for shelter rights' (Joint workshop for Tudor, Mzizima and Changamwe Tenants' Associations Mombasa, Kenya, 15 and 24 April 2003).

5. International Covenant on Economic, Social and Cultural Rights, article 11 .

6. Universal Declaration of Human Rights, article 1 ('All human beings are born free and equal in dignity and rights').

\section{References}

Harris-Curtis, E., 2003, The Implications of Adopting Rights-based Approaches for Northern NGOs: A Preliminary Exploration, Oxford: International NGO Training and Research Centre

East African Standard, 1995, 'We won't pay new rates: tudor tenants tell council', 7 July, ILISHE Trust, 2002, Land and Shelter Rights Struggles of Communities: 72-73

Kenya Central Bureau of Statistics, 2003, Geographic Dimension of Well-being in Kenya: Where do the Poor Live? From District to Location?, Vol 1, Nairobi: Kenya Central Bureau of Statistics

Molyneux, M. and Lazar, S., 2003, Doing the Rights Thing: Rights-Based Development and Latin American NGOs, London: Intermediate Technology Development Group

Nyamu-Musembi, C. and Cornwall, A., 2004, 'What is the "Rights-Based Approach" all about?
7. Government of Kenya, Ministry of Roads and Public Works, Draft Sessional Paper on National Housing Policy for Kenya (July 2002). The ministry organised a consultation meeting with civil society groups on 21 March 2003, but these were only Nairobi-based groups. Comments from ILISHE's Land and Shelter committee were only invited after the event, in April 2003, even though their struggles were key in highlighting the need for a national policy on housing. See 'The New National Housing Policy: Some Gaps' (input by civil society groups to a consultative forum held at the Kenya School of Monetary Studies, 21 March 2003). See also Notes of Focus Group Discussion on Housing Policy, Lenana Mount Hotel, 26 February 2003.

Perspectives from International Development Agencies', IDS Working Paper 234, Brighton: Institute of Development Studies

Nyamu-Musembi, C. and Musyoki, S., 2004, 'Kenyan civil society perspectives on rights, rights-based approaches and participation', IDS Working Paper 236, Brighton: Institute of Development Studies

Offenheiser, R.C. and Holcombe, S., 2001, 'Challenges and opportunities of implementing a rights-based approach to development: an Oxfam America perspective', paper presented at conference on 'Northern Relief and Development NGOs: New Directions in Poverty Alleviation and Global Leadership Transitions', 2-4 July, Balliol College, Oxford, UK 